\title{
AN OUTBREAK OF CUTANEOUS LEISHMANIASIS AMONG SOLDIERS IN BELÉM, Pará State, Brazil, CAuSed by LeISHMania (VIANNIA) LINDENBerGI N. SP.
}

\author{
A NeW leIshmanial parasite of MAN IN the AMAZON REGION
}

\author{
SILVEIRA F.T.*, ISHIKAWA E.A.Y.*, DE SOUZA A.A.A.* \& LAINSON R.*
}

Summary :

Eight cases of cutaneous leishmaniasis are recorded among soldiers of the Brazilian Forest Infantry stationed in Belém, State of Pará, north of Brazil. The infections, all acquired during manoeuvres in nearby degraded primary forest, are attributed to a new member of the subgenus Viannia, Leishmania (V.) lindenbergi $\mathrm{n}$. sp. A further infection by this parasite was encountered in a woman, who lived very close to the same piece of forest. The new parasite has been characterised and differentiated from other known species of the subgenus Viannia following the combined use of enzyme electrophoresis and monoclonal antibodies techniques. The eco-epidemiology of L. (V.) lindenbergi is discussed: by far the most abundant anthropophilic sandfly in the type locality was identified as Lutzomyia (Nyssomyia) antunesi (Coutinho), and this remains high on the list of possible vectors.

KEY WORDS : Leishmania (Viannia) lindenbergi n. sp., cutaneous leishmaniasis, Pará State, Brazil.

\section{INTRODUCTION}

I $n$ the Amazon Region of Brazil the situation regarding cutaneous leishmaniasis of man is complicated by the presence of several different species of Leishmania circulating in enzootics involving a wide variety of wild mammalian hosts and different phlebotomine sandfly vectors (Lainson \& Shaw, 1987, 1997; Lainson et al., 1994; Shaw \& Lainson, 1987; Silveira et al., 1991a, b; Souza et al., 1996). In the State of Pará alone, there are at present six recognised species of Leishmania responsible for dermal leishmaniasis, namely: Leishmania (Viannia) brazilienisis Vianna 1911; L. (V.) guyanensis Floch 1954; L. (V.) lainsoni Silveira et al., 1987; L. (V.) shawi Lainson et al., 1989; L. (V.) naiffi Lainson \& Shaw, 1989; and Leishmania (Leishmania) amazonensis Lainson \& Shaw, 1972.

Recently we have studied a small outbreak of cutaneous leishmaniasis among soldiers of the $2^{\text {nd }}$ Batallion of the Forest Infantry ( $2^{0}$ BIS), stationed in Belém, who have been engaged in military manoeuvres in a nearby area of degraded primary forest. In addition, a

\footnotetext{
* Departamento de Parasitologia, Instituto Evandro Chagas (FNS), Caixa Postal 1128, Belém, Pará, Brazil.

Correspondence: R. Lainson. Fax: (55.91) 226-1284.
}

Résumé : LEISHMANIA (VIANNIA) LINDENBERGI N. SP. RESPONSABLE DE

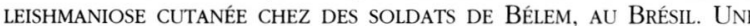
NOUVELLE LEISHMANIE PARASITE DE L'HOMME EN RÉGION AMAZONIENNE

Huit cas de leishmaniose cutanée ont été observés chez des militaires stationnés à Bélem, dans l'État de Para, au nord du Brésil. Les infections, contractées durant des manœuvres dans la forêt primaire dégradée, sont attribuées à un nouveau membre du sous-genre Viannia, Leishmania (V.) lindenbergi n. sp. Une autre infection par ce parasite a été observée chez une femme vivant dans la même région forestière. Ce nouveau parasite a été différencié des autres espèces connues du sous-genre Viannia par les techniques d'électrophorèse enzymatiques et d'anticorps monoclonaux. L'éco-épidémiologie de L. (V.) lindenbergi est discutée : Lutzomyia (Nyssomyia) antunesi (Coutinho), très abondant dans cette région, apparait en premier sur la liste des possibles vecteurs

MOTS CLÉS : Leishmania (Viannia) lindenbergi n.sp., leishmaniose cutanée, Pará, Brésil.

further case was detected in an adult, female civilian living in quarters adjacent to the military barracks. In all cases the isolated parasite proved to be identical, and it was with some surprise that we found it to differ from all the above-mentioned species of Leishmania recorded in the Brazilian Amazon Region, and some other parts of Latin America, as indicated by our routine methods of characterization. It is the object of this communication to describe the parasite and name it Leishmania (Viannia) lindenbergi $\mathrm{n}$. sp., in honour of Adolpho Lindenberg, who was the first person to detect Leishmania in cutaneous lesions in Brazil, in patients suffering from "úlcera de Bauru" (cutaneous leishmaniasis) in the State of São Paulo, Brazil.

\section{MATERIALS AND METHODS}

\section{PATIENTS}

A total of eight soldiers and an adult female civilian, examined in the out-patients department of the leishmaniasis programme of the Instituto Evandro Chagas, in Belém, during the period February to May, 1996, presented with cutaneous lesions suggestive of leishmaniasis. 


\section{CLINICAL DiagnOSIS}

Following registration, each patient was questioned regarding the probable locality in which the infection was acquired, the period of incubation, number of lesions, and their morphology and location on the body. The clinical details of these cases are given in Table I.

\section{LABORATORY DIAGNOSIS}

All patients were submitted to the following procedures: a) smears of exudate from the border of lesions were air dried, fixed in absolute methyl alcohol, and stained by Giemsa's method to confirm the presence of leishmanial amastigotes; b) intradermal Montenegro skin tests were performed with leishmanin antigen to evaluate the delayed hypersensitivity cellular response according to Silveira et al. (1991c); and c) biopsies were triturated in physiological saline for intradermal inoculation into the hind feet of pairs of hamsters, which were examined at weekly intervals for the development of cutaneous lesions containing leishmanial amastigotes.

\section{IDENTIFICATION OF LEISHMANIAL PARASITES ISOLATED FROM PATIENTS}

Identification of isolates was based on the following data: a) morphology of amastigotes and promastigotes; b) mode of development of lesions in the skin of the inoculated hamsters; c) subsequent behaviour of promastigotes in culture medium; d) a comparison of the isoenzyme electrophoretic profiles of each isolation with those of the recognised Leishmania species of the Amazon Region of Brazil; and e) other comparisons using monoclonal antibodies (McAbs).

Morphology of amastigotes and promastigotes

For preparations of amastigotes, smears of exudate from the patients' lesions were quickly air-dried, fixed in absolute methyl alcohol and stained with Giemsa. To obtain promastigotes, skin was taken from the sites of inoculation in the hamsters and cultured in Difco B45 blood-agar medium. The flagellates of seven-dayold cultures were washed by centrifugation in buffered physiological saline (PBS) and smears stained by a modified Giemsa method (Lainson, 1959). Measurements of amastigotes and promastigotes were made using the oil immersion lens, $\times 10$ oculars and an eyepiece micrometer. All measurements are given in $\mu \mathrm{m}$.

Enzyme electrophoresis

We used the enzymes MPI, 6PGDH, GPI, G6PD, PK, $\mathrm{NH}, \mathrm{MDH}, \mathrm{PGM}, \mathrm{ASAT}$ and ALAT on nitrocelulose acetate membrane (Miles et al., 1980 for methods and abbreviations), and the profiles of the newly isolated parasites were compared with those of $L$. (V.) braziliensis (MHOM/BR/75/M2903) from Serra dos Carajás, Pará; L. (V.) guyanensis (MHOM/BR/75/M4147) from Monte Dourado, Pará; L. (V.) lainsoni (MHOM/BR/81/ M6426) from Benevides, Pará; L. (V.) shawi (MCEB/BR/ 84/M8408) from Serra dos Carajás (Parauapebas), Pará; L. (V.) naiffi (MDAS/BR/79/M5533) from Tucuruí, Pará; and L. (L.) amazonensis (IFLA/BR/67/PH8) from Utinga, Belém, Pará.

\section{Monoclonal antibodies}

The leishmaniasis programe of the IEC uses a battery of 23 McAbs against the above-mentioned Amazonian species of Leishmania, and others against those from other neighbouring parts of South America (McMahon Pratt et al., 1986; Hanham et al., 1991). We used these by way of the indirect imunofluorescence/fluoresceinlabelled avidin technique (Shaw et al., 1989).

\section{TREATMENT OF PATIENTS}

At the time of these studies we were collaborating with the Nucleus of Tropical Medicine, Federal University of Pará, in a project to evaluate the efficiency of the antimalarial drug mefloquine in the treatment of cutaneous leishmaniasis and, for this purpose, the eight patients were divided into two groups and treated as follows:

1 - Four of the soldiers were given the conventional treatment with Glucantime ${ }^{\circledR}$ (meglumine antimoniate), at a daily dosage of $15 \mathrm{mg}$ Sbv per kilo weight during 20 days, with a repetition of this course of intravenous injections after an interval of 10 days.

2 - With their agreement, the remaining four soldiers and the female civilian patient received a single oral dose of $250 \mathrm{mg}$ mefloquine, daily, for 10 consecutive days. Patients failing to show complete healing of the lesion were given a second course of treatment after an interval of 30 days. This was for six days at the same dosage. If the lesion still persisted 30 days after this second course of mefloquine, this treatment was considered to be ineffectual. All these patients underwent kidney and liver function examination prior to treatment, and any side-effects were also considered in evaluating the drug's effectiveness.

\section{ECOLOGICAL AND EPIDEMIOLOGICAL STUDIES}

In attempts to locate the transmission area, we endeavoured to trace each patient's movements during a period of about three months before their lesions were first noted. The major area of contact established, night time collections of phlebotomine sandflies attracted to man and to Shannon-traps were made on six and eleven occasions, respectively, between the hours of 18:00-20:30. Disney-traps (Disney, 1966) using young specimens of laboratory-bred Proechmyis guya- 
nensis and the primate Cebus apella as bait animals were set on two occasions, each between the hours 18:00-8:00. Other captures were made with CDC miniature light traps at ground level (eleven times, using four CDCs) and in the forest canopy (five times, using two CDCs). These collections were made during the period October $30^{\text {th }} 1996$ to February $2^{\text {th }} 1998$.

Sandflies returned to the laboratory were dissected for evidence of infection with leishmanial promastigotes (Lainson, 1997).

\section{RESULTS}

\section{ClinICAL AND LABORATORY DIAGNOSIS}

Data regarding the clinical and laboratory diagnosis of the patients are given in Table I.

\section{MORPHOLOGY OF AMASTIGOTES AND PROMASTIGOTES}

With the exception of $L$. (V.) lainsoni, the amastigotes and promastigotes of which have peculiar characteristics (Silveira et al., 1987), L. (V.) lindenbergi n. sp. showed no morphological features enabling its differentiation from the other members of the subgenus Viannia. The mean measurements of amastigotes (Figs 1-4) was $3.3 \times 1.6$ (range $2.2 \times 1.5-3.7 \times 2.2$ ). As seen in log phase cultures, the mean body measurements of promastigotes (Fig. 5) were $8.1 \times 2.8$ (range $3.7 \times 3.0-12.6 \times 2.2$.), and the free flagellum varied from 6.0 to 22.0 in length.

\section{BEHAVIOUR OF THE PARASITE IN THE HAMSTER}

Inoculated hamsters were examined between twothree months after they had been inoculated with material from patients' skin lesions. None of the animals had developed a visible skin lesion, but the para- site was isolated in cultures of skin taken from the site of inoculation of material from 4 of the soldiers and the female patient. Amastigotes were extremely scanty or undetectable in Giemsa stained smears of hamster skin.

\section{BeHAVIOUR OF THE PARASITE \\ in DifCo BloOd-Agar CUlture medium}

Growth was discrete to moderate, typical of most species within the subgenus Viannia.

\section{ISOENZYME PROFILES}

All the isolates from the five patients (four soldiers and the female civilian) were indistinguishable on profiles for the 10 enzymes utilized, and separable from $L$. (V.) braziliensis, L. (V.) guyanensis, L. (V.) shawi and $L$. (V.) naiffi $i$ by the profiles of enzymes 6PGDH, GPI, ASAT and MPI. Moreover, these isolates were also separable from $L$. (V.) braziliensis, L. (V.) guyanensis and $L$. (V.) shawi by the profiles of enzymes G6PD and ALAT, but not from $L$. (V.) naiffi (Fig. 6). We did not include $L$. (V.) lainsoni and $L$. (L.) amazonensis in the isoenzyme analysis because they may be separated from L.(V.) lindenbergi n.sp. by their morphology.

\section{MONOCLONAL ANTIBODIES}

The new parasite is clearly a member of the subgenus Viannia, as shown by its reaction with the McAbs B2 and B12 which are specific for this taxon (McMahonPratt et al., 1982, 1985). Neverthless, it could be distinguished from the other members of the subgenus Viannia for the following reasons: a) it did not react against the McAbs B18 and B19 which are specific for L. (V.) braziliensis and L. (V.) guyanensis, respectively; b) it failed to react against the McAb N3 which, in association with the McAb N2, recognises $L$. (V.) naiffi; c) it differed from $L$. (V.) shawi, which does not react

\begin{tabular}{|c|c|c|c|c|c|c|c|c|c|c|c|}
\hline \multirow{2}{*}{$\begin{array}{c}\text { Patients } \\
\mathbf{N}^{\circ}\end{array}$} & \multirow{2}{*}{$\begin{array}{l}\text { Age } \\
\text { /Sex }\end{array}$} & \multirow{2}{*}{$\begin{array}{c}\text { Professional } \\
\text { activity }\end{array}$} & \multirow{2}{*}{$\begin{array}{c}\text { Locality } \\
\text { of } \\
\text { infection }\end{array}$} & \multirow{2}{*}{$\begin{array}{c}\text { Time } \\
\text { disease } \\
\text { (months) }\end{array}$} & \multirow[b]{2}{*}{$\mathbf{N}^{\circ}$} & \multicolumn{2}{|c|}{ Cutaneous lesions } & \multirow{2}{*}{$\begin{array}{c}\text { Montenegro } \\
\text { skin-test }\end{array}$} & \multirow{2}{*}{$\begin{array}{c}\text { Parasitological } \\
\text { examination }\end{array}$} & \multirow{2}{*}{$\begin{array}{l}\text { Hamster } \\
\text { inoculation }\end{array}$} & \multirow{2}{*}{$\begin{array}{l}\text { Culture } \\
\text { medium }\end{array}$} \\
\hline & & & & & & Local & Type & & & & \\
\hline 1 & $20 / \mathrm{M}$ & military & Belém/PA & 03 & 01 & left forearm & ulcerated & $\mathrm{nr}$ & + & + & - \\
\hline 2 & $19 / \mathrm{M}$ & military & Belém/PA & 03 & 01 & right forearm & ulcerated & $\mathrm{nr}$ & + & + & + \\
\hline 3 & $20 / \mathrm{M}$ & military & Belém/PA & 05 & 01 & right fist & ulcerated & $\mathrm{nr}$ & + & + & - \\
\hline 4 & $20 / \mathrm{M}$ & military & Belém/PA & 04 & 01 & right leg & ulcerated & + & + & + & + \\
\hline 5 & $20 / \mathrm{M}$ & military & Belém/PA & 03 & 01 & left forearm & ulcerated & + & + & + & + \\
\hline 6 & $19 / \mathrm{M}$ & military & Belém/PA & 03 & 02 & $\begin{array}{l}\text { right and left } \\
\text { hands }\end{array}$ & ulcerated & + & + & + & + \\
\hline 7 & $20 / \mathrm{M}$ & military & Belém/PA & 01 & 01 & right forearm & ulcerated & + & - & $\mathrm{nr}$ & $\mathrm{nr}$ \\
\hline 8 & $21 / M$ & military & Belém/PA & 01 & 02 & $\begin{array}{l}\text { right forearm } \\
\text { and left thigh }\end{array}$ & ulcerated & $\mathrm{nr}$ & + & + & - \\
\hline 9 & $44 / F$ & housekeeper & Belém/PA & 02 & 01 & right leg & infiltrative & $\mathrm{nr}$ & + & + & + \\
\hline
\end{tabular}

Table I. - The clinical and laboratorial observations on the nine patients suffering from cutaneous leishmaniasis caused by $L$. (V.) lindenbergi n. sp., Belém, Pará, Brazil. nr = not made. 


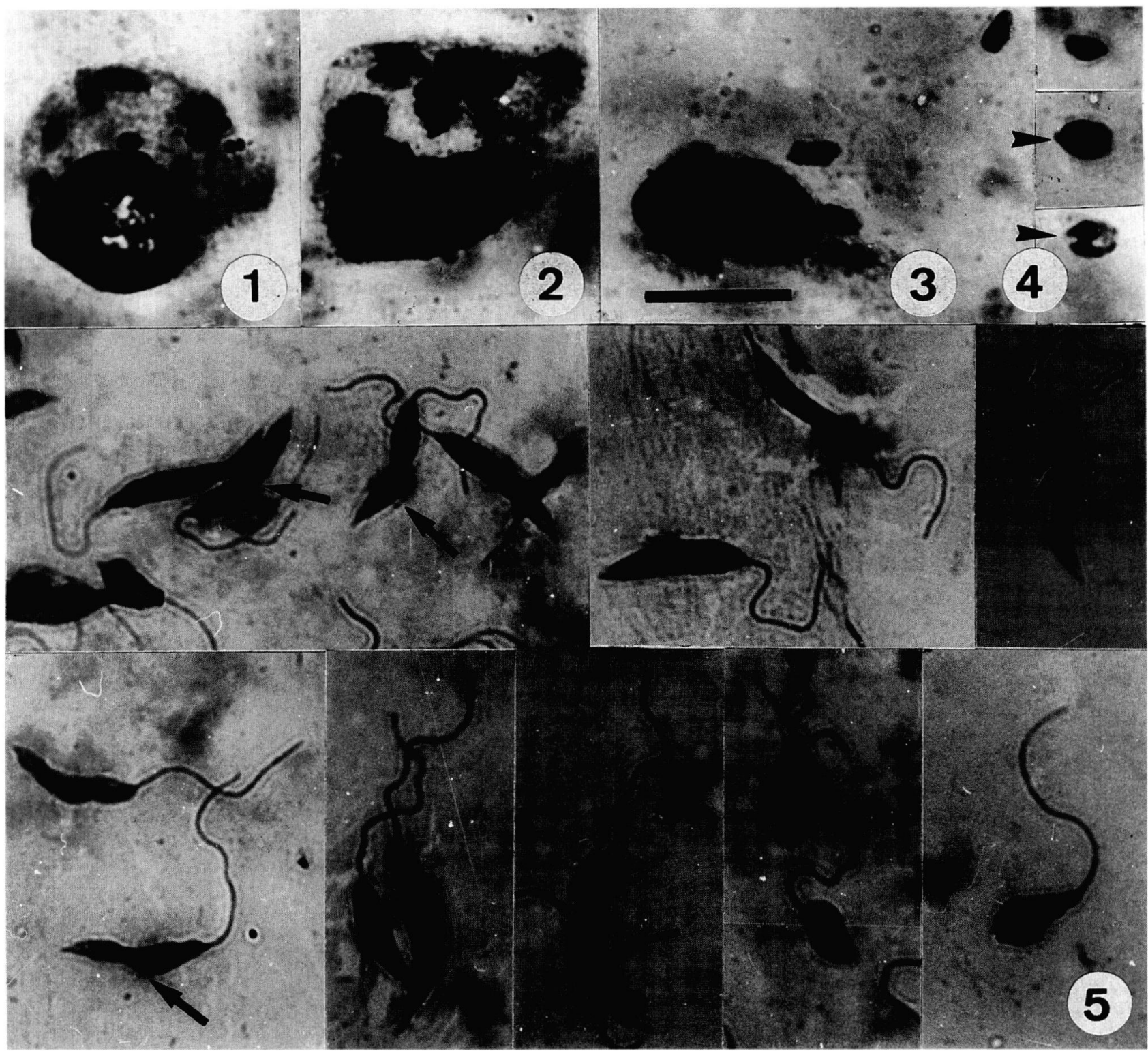

Figs 1-5 - Leishmania (Viannia) lindenbergi n. sp. Figs 1-4: Intracellular and extracellular amastigotes in a Giemsa-stained smear of exudate from the cutaneous lesion of a patient. Some parasites are in division (arrow-heads). Fig. 5: Giemsa-stained promastigotes from a 7 day-old culture, showing a variety of short, stumpy and elongated forms and a dividing parasite (arrow-head). Elongated promastigotes are frequently twisted upon themselves (arrowed). $\mathrm{Bar}=10 \mu$.

\begin{tabular}{|c|c|c|c|c|c|c|c|c|c|c|c|}
\hline \multirow[b]{2}{*}{ Species of Leishmania } & \multicolumn{11}{|c|}{ Monoclonal antibodies } \\
\hline & $\mathrm{B} 2$ & $\mathrm{~B} 12$ & B5 & $\mathrm{B} 18$ & B19 & N2 & N3 & M2 & W1 & WA2 & LA2 \\
\hline L. (V.) braziliensis & $\mathrm{X}$ & $\mathrm{X}$ & $\mathrm{X}$ & $\mathrm{X}$ & & $\mathrm{X}$ & & & & & \\
\hline L. (V.) guyanensis & $\mathrm{X}$ & $\mathrm{X}$ & & & $\mathrm{x}$ & & & & & & \\
\hline L. (V.) shawi & $\mathrm{X}$ & $\mathrm{X}$ & & & & & & & & & \\
\hline L. (V.) naiffi & $\mathrm{X}$ & $\mathrm{X}$ & & & & $\mathrm{X}$ & $\mathrm{X}$ & & & & \\
\hline L. (V.) lainsoni & & & & & & & & & & & $\mathrm{X}$ \\
\hline L. (V.) amazonensis & & & & & & & & $\mathrm{X}$ & $\mathrm{X}$ & $\mathrm{x}$ & \\
\hline L. (V.) lindenbergi & $\mathrm{X}$ & $\mathrm{X}$ & & & & $\mathrm{X}$ & & & & & \\
\hline
\end{tabular}

Table II. - Comparison of the serodeme profiles among Leishmania (V.) lindenbergi n. sp. and the other species of Leishmania in the Amazon Region, Brazil. 


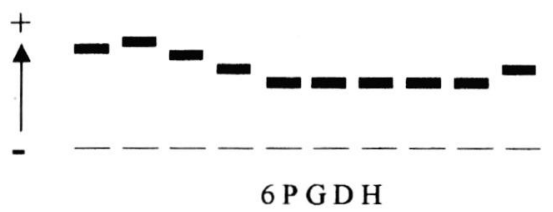

6 P G D H

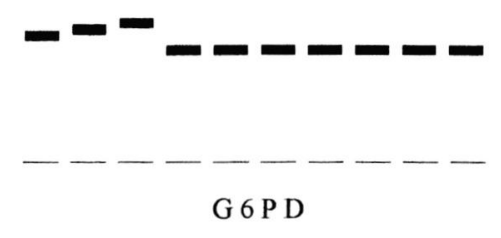

G 6 P D

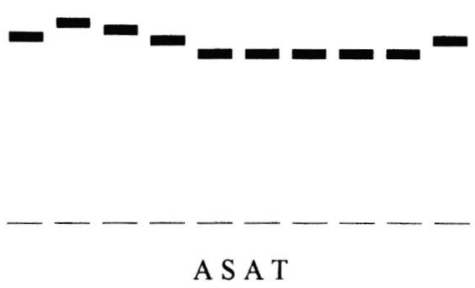

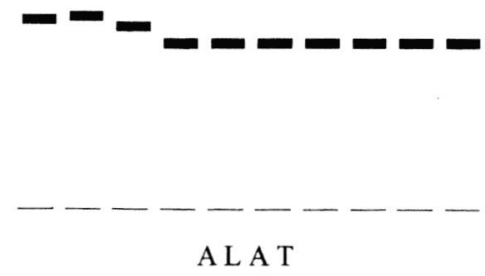

A L A T

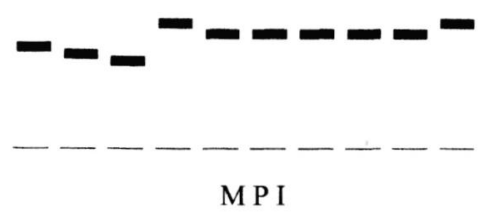

Fig. 6. - Identification of Leishmania (Viannia) lindenbergi n. sp. infecting man, by isoenzyme profiles. Six of 10 enzymes are shown: 6PGDH, G6PD, ALAT, GPI, ASAT, MPI. The parasites compared, from left to right are: 1) L. (V.) braziliensis; 2) L. (V.) guyanensis; 3) L. (V.) shawi; 4 and 10) L. (V.) naiffi; 5, 6, 7,8 and 9) $L$. (V.) lindenbergi $\mathrm{n}$. sp. Scale: the distance between the points of origin of each parasite is $1,0 \mathrm{~cm}$.

against the McAb N2; and d) it differed from L. (V.) lainsoni and $L$. (L.) amazonensis which do not react against the McAbs B2 and B12 (Table II).

\section{TREATMENT OF PATIENTS}

With the exception of the female civilian patient, for whom it was necessary to interrupt the mefloquine treatment during the first series, due to the side-effects of this drug (epigastralgia, bloated feeling and dizziness), the four soldiers also treated with mefloquine, in two series, was cured of the disease at the final time of almost 90 days. For the female civilian patient, treatment was changed to meglumine antimoniate and, together with the soldiers, she was considered to be cured after two series of this drug.

\section{ECOLOGICAL AND EPIDEMIOLOGICAL STUDIES}

Acquisition of infection among the soldiers was clearly during their nightime manoeuvres in the forest area of the $2^{\text {nd }}$ Batallion of the Forest Infantry ( $\left.2^{0} \mathrm{BIS}\right)$, stationed in Belém. In the case of the single female civilian it remained uncertain. She denied having entered the area of forest frequented by the soldiers and, as this was very close to the quarters in which she lived, it is possible that she was bitten by sandflies attracted by the lights of her rooms.

The results of phlebotomine sandfly captures, made in the area where the human infections ocurred, can be seen in Table III. A total of 3,179 female sandflies within 29 species was examined and on no occasion was leishmanial infection detected. Neverthless, it is interesting to mention the significant prevalence of $50,7 \%$ for the phlebotomine Lutzomyia antunesi among the species captured, and its predominance $(83,7 \%)$ within the anthropophilic sandflies captured.

\section{LEISHMANIA (VIANNIA) LINDENBERGIN. SP.}

Specific diagnosis

Type host: man. Silvatic reservoir-hosts as yet unknown.

Locality in host: amastigotes localized in skin lesions. Type locality: in degraded, residual forest on the outskirts of Belém, Pará, north Brazil.

Strain designation: MHOM/BR/1996/M15.733 (Belém, Pará, Brazil).

Amastigotes (Figs 1-4): $3.3 \times 1.6(2.2 \times 1.5-3.7 \times 2.2)$ for 50 measured.

Promastigotes (Fig. 5): body $8.1 \times 2.8(3.7 \times 3.0-12.6 \times$ 2.2 ); free flagellum varying from 6.0 to 22.0 in length: for 50 measured.

Development in the sandfly host: although the natural vector is as yet unknown, development of the parasite in experimentally infected, laboratory-bred Lutzomyia longipalpis is typical of Leishmania species within the subgenus Viannia, with prolific growth of flagellates 


\begin{tabular}{|c|c|c|c|c|c|c|}
\hline \multirow[b]{2}{*}{ Sandflies species } & \multirow[b]{2}{*}{ CDC } & \multirow[b]{2}{*}{ Shannon-trap } & \multicolumn{2}{|c|}{ Methods of catch } & \multirow[b]{2}{*}{ Human bait } & \multirow[b]{2}{*}{ Total } \\
\hline & & & $\begin{array}{l}\text { Disney-trap } \\
\text { (Proechimys) }\end{array}$ & $\begin{array}{l}\text { Disney-trap } \\
\text { (Cebus) }\end{array}$ & & \\
\hline Lu. anduzei & & 4 & & & 2 & 6 \\
\hline Lu. antunezi & 241 & 697 & & & 675 & 1,613 \\
\hline Lu. aragao $i$ & 9 & 1 & & & & 10 \\
\hline Lu. bacula & 1 & & & & & 1 \\
\hline Lu. barretoi & 51 & 7 & & & & 58 \\
\hline Lu. flaviscutellata & 41 & 11 & 41 & 81 & 2 & 176 \\
\hline Lu. furcata & 1 & 4 & & & & 5 \\
\hline Lu. gomezi & 7 & 8 & & & 11 & 15 \\
\hline Lu. infraspinosa & 7 & & & & & 7 \\
\hline Lu. nordestina & 3 & 86 & & & & 89 \\
\hline Lu. osvaldo $i$ & & 39 & & & & 39 \\
\hline Lu. pacae & & 89 & & & & 89 \\
\hline Lu. pinotii & & 85 & & & & 85 \\
\hline Lu. rorotaensis & 4 & 43 & & & & 47 \\
\hline Lu. saulensis & 1 & 22 & & & & 23 \\
\hline Lu. scaffi & 1 & 51 & & & & 52 \\
\hline Lu.shannoni & 1 & & & & & 1 \\
\hline Lu. shawi & & 24 & & & & 24 \\
\hline Lu. spinosa & & 2 & & & & 2 \\
\hline Lu. trichopyga & 1 & 13 & & & & 14 \\
\hline $\mathrm{Br}$. avelari & 16 & & & & & 16 \\
\hline Br. travassosi & 23 & & & & & 23 \\
\hline Ps. ayrozai & 1 & 15 & & & 2 & 18 \\
\hline Ps. claustrei & & 1 & & & & 1 \\
\hline Ps. corossoniensis & & 4 & & 2 & & 6 \\
\hline Ps. davisi & 76 & 256 & 9 & 8 & 30 & 379 \\
\hline Ps. geniculatus & 20 & 147 & & & 36 & 203 \\
\hline Ps. hirsutus & & 19 & & & 6 & 25 \\
\hline Ps. paraensis & 15 & 95 & & & 42 & 152 \\
\hline
\end{tabular}

Table III. - Sandfly collections made in the area of $2^{\text {nd }}$ Batallion of the Forest Infantry $\left(2^{0}\right.$ BIS $)$, Belém, Pará, Brazil, during the period between October $30^{\text {th }} 1996$ to February $2^{\text {th }} 1998$.

attached to the wall of the hind-gut, particularly the pylorus wall.

Behaviour in hamster: no visible lesion produced at the site of intradermal inoculation of amastigotes twothree months later, but presence of very scanty parasites confirmed by positive cultures in blood-agar medium (Difco B45).

Behaviour in in-vitro culture: discrete to moderate growth of promastigotes.

Sandfly vector: unknown. Lutzomyia antunesi is highly suspected.

Isoenzymes profiles: the enzymes 6PGDH, G6PD, ALAT, GPI, ASAT and MPI can be used for distinguishing it from the other species of parasites in the subgenus Viannia.

Monoclonal antibodies: B2, B12 and N2 are the major epitopes used to recognize $L$. (V.) lindenbergi.

Type material: hapantotype slides (amastigotes and promastigotes) held in the Department of Parasitology, the Instituto Evandro Chagas, Belém, Pará, Brazil. Cultures maintained in the cryobank of the same institute.

\section{DISCUSSION}

L (V.) lindenbergi n.sp. is clearly very similar to $L$. (V.) naiffi in its production of inapparent skin infections in inoculated hamsters, isoenzyme profiles and monoclonal antibodies. The rare production of a visible skin lesion in hamsters inoculated with these two parasites may mean that human infections have frequently been missed in past studies utilizing these animals as the means of isolation (Lainson et al., 1994). From the present studies L. (V.) lindenbergi would appear to more commonly infect man than does $L$. (V.) naiffi. This is possibly due to differences in the attraction that man has for their respective vectors. It remains for continuing epidemiological studies to more clearly indicate the importance of $L$. $(V$.) lindenbergi among the various parasites responsible for human cutaneous leishmaniasis. We have shown that in the forest where the infections were acquired the most common man-biting sandfly was Lu. antunesi. This sandfly is a low-flying, highly anthropophilic insect, as shown by our captures with human bait, when most of them were taken from the legs and feet. In this res- 
pect it is of particular interest that the soldiers spent much of their time standing in slit-trenches, so that their head and resting arms were at ground level: most of their lesions were on these parts of the body. If $L u$. antunesi is indeed the vector then human infection with $L$. (V.) lindenbergi may well be of common occurrence in other areas where the population of $\mathrm{Lu}$. antunesi is at high density.

With regards the enzyme profiles (zymodeme) of $L$. (V.) lindenbergi n.sp., these clearly indicate the parasite's close relationship with $L$. (V.) naiffi. With four of the enzymes used (6PGDH, GPI, ASAT and MPI), however, it is possible to separate the two organisms.

$L$. (V.) lindenbergi n. sp., was only differentiated by the McAb N2, originally produced to react against $L$. (V.) naiffi, and we verified that there was no reaction against the McAb N3 which is species-specific for the latter parasite (Hanham et al., 1991a, b). In addition, although the McAb N2 also reacts against $L$. (V.) braziliensis, we observed no reaction of the isolates of $L$. ( $V$.) lindenberg $i$ with the McAb B18, which is species-specific for L. (V.) braziliensis (Shaw et al., 1986). In conclusion, we consider that the serodeme profile of $L$. ( $V$.) lindenberg $i$ is characterized by the parasite's reaction with the McAbs $\mathrm{B} 2, \mathrm{~B} 12$ (specific for the subgenus Viannia) and N2.

Although it is inappropriate to discuss the treatment of patients here in any length, it is of interest to note that after healing of their lesions, none showed further indication of infection after one year's follow-up. The apparent cure following mefloquine treatment of four patients suggests this drug to be effective against $L$. (V.) lindenbergi (although spontaneous cure can not be discluded). This finding contrasts with the poor results obtained with mefloquine treatment in Colombia (Hendrickx et al., 1998), but supports success achieved in Equador (Gómez et al., 1996). The conflicting results are possibly due to the treatment of cutaneous leishmaniasis caused by different species of Leishmania. Finally, since this paper was completed, we have isolated $L$. ( $V$.) lindenberg $i \mathrm{n}$. sp., from five more cases of cutaneous leishmaniasis in Pará, as identified by the above methods. All infections have so far been associated with similar degraded primary forest on the outskirts of Belém and the neighbouring town of Ananindeua, Pará.

\section{ACKNOWLEDGEMENTS}

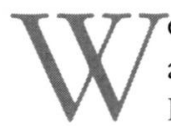
e are indebted to Drs Yoshihisa Hashiguchi and Masato Foruya, Kochi Medical School, Kochi 783, Japan, for providing facilities for one of us (EAYI) to carry out the enzyme electrophoresis studies; and to Iorlando da Rocha Barata, José
Aprígio Nunes de Lima, José Itamar de Almeida, João Batista P. da Luz, Maria das Graças Soares da Silva, Raimundo Nonato Barbosa Pires, Antônio F.P. Martins, João Alves Brandão and Constância M. Franco for valuable technical assistance. This work was supported by grant 0499426 from the Wellcome Trust, London (to FTS and RL) and by Fundação Nacional de Saúde (FNS), Ministery of Health, Brazil.

\section{REFERENCES}

DisNEY R.H.L. A trap for phlebotomine sandflies attracted to rats. Bulletin of Entomological Research, 1996, 56, 445-451.

Gómez E., Loor C. \& VAca G. Tratamento oral de la leishmaniasis americana em el Equador: primer reporte. Medicina (Quito), 1996, 2, 121-128.

Hanham C.A., Shaw J.J. \& Lainson R. Monoclonal antibodies that react with Leishmania (Viannia) naiffi. Journal of Parasitology, 1991a, 77, 680-687.

Hanham C.A., Zhao F., Shaw J.J. \& Lainson R. Monoclonal antibodies for the identification of New World Leishmania. Transactions of the Royal Society of Tropical Medicine and Hygiene, 1991b, 85, 220.

Hendrickx E.P., Agudelo S., Del P., Munoz D.L., Puerta J.A. \& Velez Bernal I.D. Lack of efficasy of mefloquine in the treatment of New World cutaneous leishmaniasis in Colombia. American Journal of Tropical Medicine and Hygiene, 1998, 59, 889-892.

LAINSON R. Atoxoplasma Garnham, 1950, as a synonym for Lankesterella Labbé, 1899. Its life cycle in the English sparrow (Passer domesticus domesticus, Linn.). Journal of Protozoology, 1959, 6, 360-371.

LAINSON R. On Leishmania enriettii and other enigmatic Leishmania species of the neotropics. Memórias do Instituto Oswaldo Cruz, 1997, 92, 377-387.

LAINSON R. \& SHAW J.J. Evolution, classification and geographical distibution. In: The Leishmaniases in biology and medicine. Vol. 1. Biology and epidemiology (Peters W. \& Killick-Kendrick R. eds). Academic Press Inc., London, 1987, 1-120.

Lainson R. \& Shaw J.J. New World Leishmaniasis - The Neotropical Leishmania Species. In: Topley \& Wilson Microbiology and Microbial Infections, ed. FEG Cox, 1997, 242266.

Lainson R., Shaw J.J., Silveira F.T., Souza A.A.A., Braga R.R. \& IsHikAwA E.A.I. The dermal leishmaniasis of Brazil, with special reference to the eco-epidemiology of the disease in Amazonia. Memorias do Instituto Oswaldo Cruz, 1994, $89,435-443$.

McMahon Pratt D., Bennet E. \& David J.R. Monoclonal antibodies that distinguish subspecies of Leishmania braziliensis. Journal of Immunology, 1982, 129, 926-927.

Mcmahon Pratt D., Bennet E., Grimald G. \& Jaffe C.L. Subspecies- and specie-specific antigens of Leishmania mexicana characterized by monoclonal antibodies. Journal of Immunology, 1985, 134, 1935-1940. 
McMahon Pratt D., Jaffe C.L. , Bennet E., David J.R. \& GriMALD G. Studies employing monoclonal antibodies for analysis of the genus Leishmania Ross, 1903. In: Leishmania: Taxonomie et phylogénèse. Applications éco-épidémiologiques. Montpellier, France: IMEEE, Colloque International CNRS/INSERM/OMS, 1986, 173-178.

Miles M.A., Póvoa M.M., Souza A.A.A., Lainson R. \& SHaw J.J. Some methods for the enzymic characterization of Latin-American Leishmania, with particular reference to Leishmania mexicana amazonensis and subspecies of Leishmania hertigi. Transactions of the Royal Society of Tropical Medicine and Hygiene, 1980, 74, 243-252.

SHAW J.J. \& LAINSON R. Ecology and epidemiology: New World. In: The Leishmaniases in biology and medicine. Vol. 1. Biology and epidemiology (Peters W.\& Killick-Kendrick R. eds). Academic Press Inc., London, 1987, 291-363.

Shaw J.J., Lainson R., McMahon Pratt D. \& David J.R. Serodemes of the Leishmania braziliensis complex. In: Leishmania: taxonomie et phylogénèse. Applications écoépidémiologiques. Montpellier, France: IMEEE, Colloque International CNRS/INSERM/OMS, 1986, 179-183.

Shaw J.J., Ishikawa E.A.Y. \& LaInSOn R. A rapid and sensitive method for the identification of Leishmania with monoclonal antibodies using fluorescein-labelled avidin. Transactions of the Royal Society of Tropical Medicine and Hygiene, 1989, 83, 783-784.

Silveira F.T., Shaw J.J., Braga R.R., \& Ishikawa E.A.Y. Dermal leishmaniasis in the Amazon Region of Brazil: Leishmania (Viannia) lainsoni sp. n., a new parasite from the State of Pará. Memórias do Instituto Oswaldo Cruz, 1987, 82, 289-292.

Silveira F.T., Lainson R., Shaw J.J., Braga R.R., Ishikawa E.A.Y. \& SouzA A.A.A. Leishmaniose cutânea na Amazônia: Isolamento de Leishmania (Viannia) lainsoni do roedor Agouti paca (Rodentia: Dasyproctidae) no Estado do Pará, Brasil. Revista do Instituto de Medicina tropical de São Paulo, 1991a, 33, 18-22.

Silveira F.T., Souza A.A.A., Lainson R., Shaw J.J., Braga R.R. \& IsHIKAwA E.A.Y. Cutaneous leishmaniasis in the Amazon Region: natural infection of the sandfly Lutzomyia ubiquitalis (Psychodidae: Phlebotominae) by Leishmania (Viannia) lainsoni in Pará State, Brazil. Memórias do Instituto Oswaldo Cruz, 1991b, 86, 127-130.

Silveira F.T., Lainson R., Shaw J.J., Souza A.A.A., Ishikawa E.A.Y. \& BragA R.R. Cutaneous leishmaniasis due to Leishmania (Leishmania) amazonensis in Amazonian Brazil, and the significance of a negative Montenegro skin-test in human infections. Transactions of the Royal Society of Tropical Medicine and Hygiene, 1991c, 85, 735-738.

Souza A.A.A., Ishikawa E.A.Y., Braga R.R., Silveira F.T., LaInson R. \& Shaw J.J. Psychodopygus complexus, a new vector of Leishmania braziliensis to humans in Pará State, Brazil. Transactions of the Royal Society of Tropical Medicine and Hygiene, 1996, 90, 112-113.

Reçu le 23 mai 2001 Accepté le 24 octobre 2001 